\title{
MODELING THE INTERNET OF THINGS NETWORK FOR MONITORING AUDIO INFORMATION ON THE AMAZON PLATFORM
}

\author{
Belarusian state University of Informatics and Radioelectronics, Minsk, Republic of Belarus, vish2002@list.ru
}

\begin{abstract}
The subject of research is modeling the structure of the Internet of things (IoT) network for controlling audio information based on the IoT platform. The purpose of the article is to detail the process of modeling the audio information monitoring network based on the IoT platform. The authors proposed the structure of a multi-agent system (MAS) for monitoring audio information (MASAI). The structure of MASAI includes many agents of sound transformation, analysis of information received from them, and decision-making. It was decided to use the IoT network, which includes sound sensors, the IoT platform, the notification service, and the user's application to simulate the MASAI. The structure of this network using the Amazon platform is proposed. An algorithm for modeling the Internet of things network for analyzing audio information based on the AWS platform is presented, including simulating audio sensors, transmitting this information to the platform, sensors authenticating, processing information according to certain rules, generating notifications to a user. Detailed structure of the AWS platform is provided with a description of the functions of its components such as: device gateway, rule machine, certificate block, device copy block, database, analytics block, notification service. The algorithm for connecting devices to the AWS platform is given: creating a device certificate on the platform, creating a security policy, rules for processing information received from devices, and testing the network. The features of the algorithm for modeling the readings of sound information sensors on a smartphone are shown, steps are given for organizing its communication with the platform, performing security procedures, sending data in the form of an MQTT message, and displaying the captured audio information.
\end{abstract}

Keywords: platform, network structure, sound sensor emulation, communications, settings.

\section{Introduction}

Collecting and processing different types of sounds and their spatio-temporal effects is crucial. Using a model that embeds a representation of sound properties in sources, and rules that control their propagation through different environments, will help in both cases by tracking historical variations and predicting future changes in sound properties along space-time dimensions. In fact, such a model can represent noise levels in an urban space and help in studying noise pollution at various levels: inside a given building, in a particular public Park, or around the entire city. The model can also help predict how spatio-temporal changes might affect noise pollution levels at any of these levels, such as when a new building complex or complex community is emerging in a city.

In fact, the amplitude and effect of sound waves differ significantly in continuous spacetime dimensions. For example, the noise produced by a plane taking off is perceived by its neighbors with varying amplitudes over time: it starts out loud and then gradually decreases as it flies away. On the other hand, modeling data and especially spatio-temporal data is an important step that gives users a clear way to understand the case study and make some decisions $[1,2]$.

The authors propose is the structure of multiagent system of sound information (MASSI) monitoring of surrounding environment $[3,4]$. MASSI structure has many agents such as sound transformation, analysis of the information received from sound agents, data base, decision-making. The network of IoT can be realization such multiagent system of sound information [5]. IoT platforms are good tools for quick this realization.

\section{IoT Platforms}

To automate the creation of IoT systems, leading global companies have developed design tools in the form of IoT platforms [6, 7]. IoT platforms are becoming the central backbone of IoT deployments - the IoT platform market will reach $\$$ 22.3 billion by 2023 [8]. Due to the large volume of information received from IoT sensors, such platforms provide analytical tools for processing 
Big Data. In may 2020, the analytical company Counterpoint Research named the leading platforms for creating IoT networks and applications in terms of versatility (to meet the needs of users) and other parameters. According to Counterpoint Research's study of versatility and other parameters, the first position was taken by the Microsoft Azure platform, and the second position was taken by Amazon Web Services (AWS) [9]. Consider modeling the network for monitoring audio information using the AWS platform.

\section{Structure and composition of network emulation on the Amazon platform}

In [10], the structure of a system for collecting environmental sound information is presented. It includes sound sensors, a wireless network, and a server for processing and monitoring their readings. We will model this system based on the Amazon platform, using a smartphone as sensors [11].

We use a smartphone that will emulate an IoT device with sound sensors and send readings to the Amazon IoT platform. The platform will formulate the rule that when you receive data from our device will cause the notification service (Notification Service), which will send the user an e-mail received sound data (fig. 1).

The General algorithm of the network platform comprises the steps:

1 Sensors measure process parameters (the device receiving audio information), they interact with the IoT platform using the development system (SDK).

2 Devices send messages to the platform, which are verified by the authentication and authorization service.
3 Messages are sent to the gateway block using different network protocols, and then they are sent to the rule handler (4.1) and copied to the device copy block (4.2).

4.1 Depending on the received data, the rule handler performs pre-defined actions (5). for example, it saves data in the database, sends an SMS or e-mail notification, calls the HTTP API, sends data to the Analytics system, and so on.

4.2 The device copy block stores the current device States that are available to applications. If there is no connection to the device, block Device Shadow executes control commands from applications and syncs the current state with the device when the connection is restored.

5 Applications use this data to monitor and manage devices using the AWS API

6 Information about all devices is stored on the AWS IoT platform.

Let 's describe the detailed structure of the AWS platform, the scheme of which is shown in figure 2 , in which the following components appear:

- Jobs - perform standard actions on devices: install applications, update firmware, reboot devices, etc.

- Topics - entities of the MQTT Protocol. Messages from IoT devices are sent to specific topics.

- IAM Roles - AWS users on whose behalf rules are executed and who have access to the necessary AWS resources.

Rules consist of the following components:

- Filter - message filter for processing, set as an SQL query: Action - action to perform; Role - one or more IAM roles.

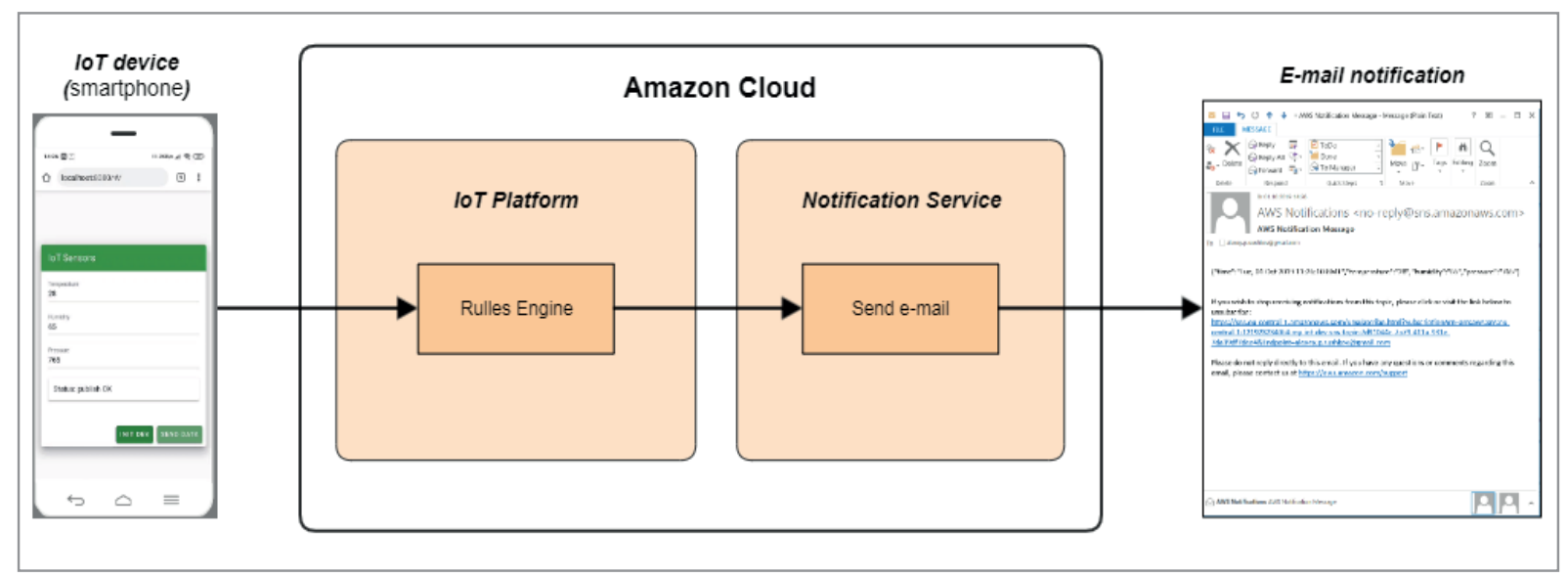

Figure 1. General structure of emulation of the IoT network on the Amazon platform 


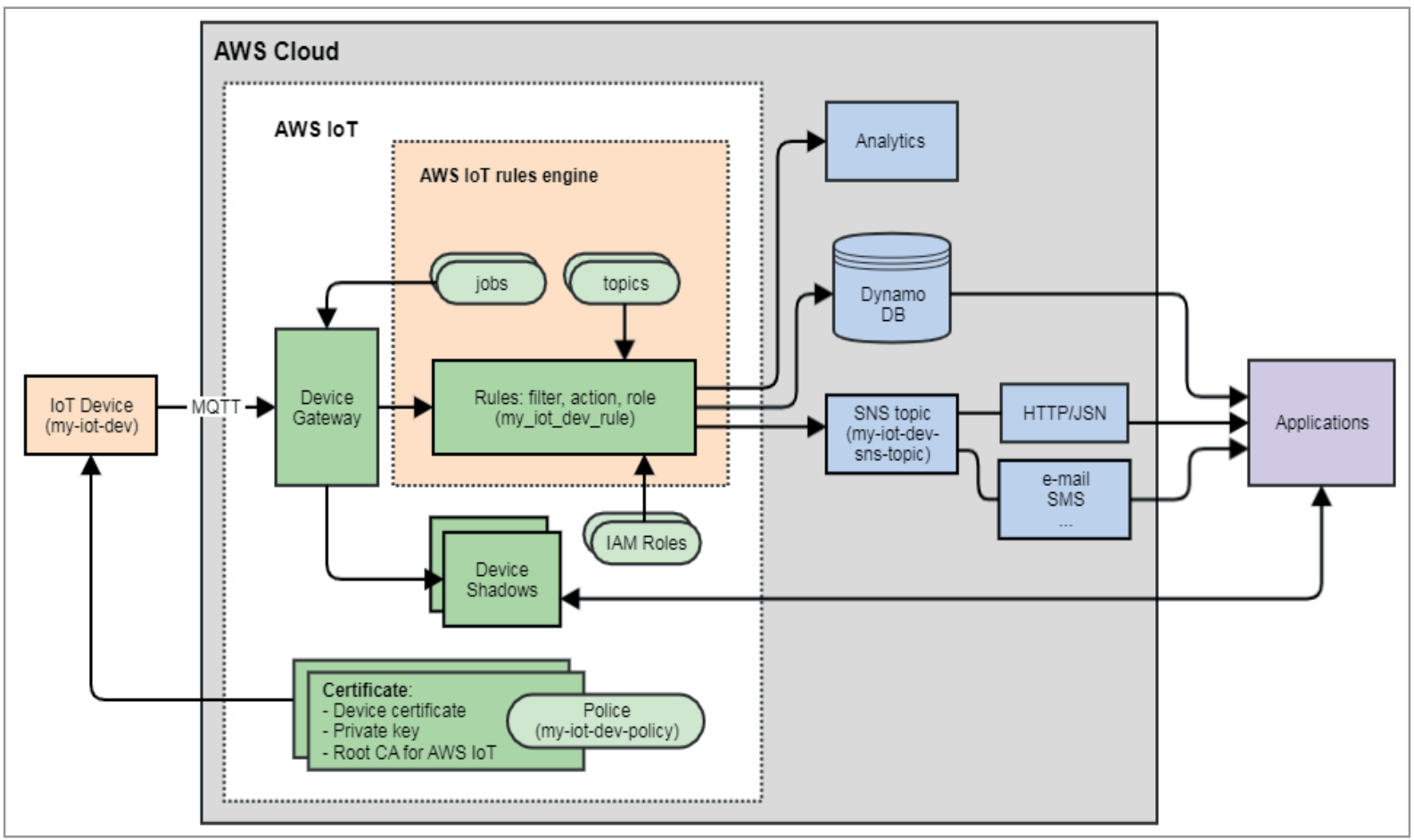

Figure 2. Detailed structure of the Amazon platform

- Certificate - uploaded to the IoT device and used for device authentication on the AWS platform. They consist of the following blocks: the X. 509 device Certificate includes: Private key; the AWS platform root certificate.

- Policy - policies are attached to certificates that determine what actions can be performed by the device. Device authorization is performed using policies.

AWS services that receive information from the IoT platform are detailed: Analytics, Data Base and SNS notification service.

\section{Connecting devices (sensors) to the platform}

Let's list the steps of the algorithm for configuring our network using [7].

1 Creating a my-iot-dev device on the platform;

1.2 Get the X. 509 device certificate using the private and public keys private key, public key;

1.3 Get the root certificate of the AWS platform (Root CA for AWS IoT).

2 Creating the my-iot-dev-policy security policy. For our version of the network, we allow all actions: iot.

2.1 Combining the created policy and the security certificate;
2.2 attaching the certificate to the device; as a Result, we have integrated the certificate with the device and the policy.

3 Creating a rule for processing information received from the device. The rule will call the AWS SNS (Simple Notification Service) notification service to send to your email address. So first you need to create a topic in AWS SNS (my-iot-dev-sns-topic).

4 Configure what this topic will do when receiving data. To do this, create a subscription to the topic (Subscribe to the Amazon SNS topic), enter the target e-mail address, wait for the verification email, and confirm the e-mail.

5 Creating the rule itself (my_iot_dev_ rule), which will call the created topic:

- Filter: SELECT * FROM 'my/dev-topic' - the filter is triggered when any message in the topic named 'my/dev-topic' is received;

- Action: sending a message to a pre-created SNS topic «arn:aws:sns:eu-central-1:1219xxx34064:my-iot-dev-sns-topic»;

- IAM role: creating the my-dev-role role with access to SNS topics.

6 All logical entities for our device are created. Now you can test that the created network diagram works. To do this, AWS has a test tool that allows you to send and receive messages in 
the same way as real devices. Launch it, subscribe to topic (my/dev-topic) and send the message "Hello World!"

7 Check that the e-mail with the message «Hello IoT!» and we conclude that IoT network is working.

\section{Emulating a device on a smartphone}

Next, you need to configure IoT devices, which will be our smartphone. To do this, we use the description [8]. To turn a smartphone into an IoT device, you need to: copy security information to the device: private key, X. 509, and "Root CA for AWS « certificates;

- Install Node.js and npm package manager;

- Install the AWS SDK;

- Install and run the test program.

In our network, everything will be easier, because the certificates, AWS SDK, and test program are recorded on GitHub and you can clone the repository [10]. You can also use the test program provided by the AWS SDK.

Android OS is based on Linux OS, but with its own limitations, so to run JS applications, you need to install a special terminal, for example, Termux. For the initial development of Termux, there are a number of articles, we use [9]. After installing Termux, you need to run several commands:

git clone github.com/AlexeySushkov/ IoT-Sensors.git

installing

the cd $\sim /$ IoT-Sensors/server server

npm install

npm start

If everything was successful, the terminal will display the line: Server started on port: 8081 . Next, enter the commands for installing the client:

$\mathrm{Cd} \sim /$ IoT-Sensors/client

npm install

npm run serve

If everything was successful, the following line will appear in the terminal: App running at port: 8080 . Next, enter the code in the smartphone browser: http://localhost:8080, the test app will appear on the screen.

\section{Modeling the operation of sensors and the network}

Click the «INIT DEV» button. This process authenticates and authorizes the IoT device on the AWS IoT platform. The status becomes «Init $\mathrm{OK} »$, if the execution is success.

Next, enter the values of the sound sensor readings in Dcb units, for example: Sound1: 23; Sound2: 35; Sound2: 42, then click the «SEND DATA» button.

After that, the application adds a timestamp and sends the data as an MQTT message to the «my/ dev-topic» topic. The IoT platform receives the message and activates a rule that sends the message to the AWS SNS notification service, which sends an e-mail with the received data in JSON format:

\{«time»: «Mon, Oct 122020 13:54:52 GMT», «Sound $1 »$ : «23», «Sound2»: «35», «Sound $3 »$ : $« 48 »\}$

If the message is sent successfully, the status changes to: "publish OK" and it is sent to the email address. e-mail.

The AWS IoT platform has a monitoring system that shows the number of connections and messages from IoT devices, statistics on protocols, message types, and so on.

\section{Conclusion}

1. The simulated operating network of the IoT, using the platform from Amazon. The General algorithm for working with the platform is given. The detailed structure of the platform is described, indicating the functions of its components.

2. Algorithm for configuring the IoT network and monitoring audio information based on the Amazon platform is Presented. The sequence of the process of modeling sound sensors using a smartphone with the output of information in the form of an email to the user is shown.

\section{REFERENCES}

1. Moisuc B., Gensel J., Davoine P., Martin H. Designing Adaptive Spatio-temporal Information Systems for Natural Hazard Risks with ASTIS // Web and Wireless Geographical Information Systems, 2006.- Pp. 146-157.

2. Parent C., Spaccapietra S., Zimányi E. Semantic modeling for geographic information systems. Encyclopedia of Database Systems, 2009.- Pp. 2571-2576.

3. Visniakou, U.A. Approach to distributed multi-agent system for processing sound information of the environment / U.A. Vishniakou, B. H. Shaya // System analysis and applied computer science, 2019, № 3.- Pp. 47-53. 
4. Visniakou, U.A. Intelligent multi-agent information processing technologies with blockchain for management systems / U. A. Vishniakou, B.H. Shaya, A.H. Al-Masry, S.K. Al-Haji // Collection of scientific papers OSTIS-2019.- Minsk: BSUIR, 2019.- Pp. 311-314.

5. Roslyakov, A.V. Internet of things: textbook. manual /A.V. Roslyakov, S. V. Vanyashin, A. Yu. Grebeshkov.- Samara, PGUTII, 2015.- 115 p.

6. Browse the best IoT platform in 2019. Tips for choosing a cloud solution [Electronic resource].- Mode of access: https:// www.edsson.com/ru/blog/article?id=iot-platforms. - Access date:24.04.2020.

7. IoT Platform [Electronic resource].- Mode of access:: https://iot.ru/wiki/iot-platforma.-- Access date: 20.09.2020.

8. Things to know about the IoT Platform ecosystem [Electronic resource].- Mode of access: https://iot-analytics. com/5-things-know-about-iot-platform/.-- Access date: 22.09.2020.

9. Big Data - IoT clouds: what are IoT platforms and why are they used? [Electronic resource].- Mode of access: https:// www.bigdataschool.ru/blog/iot-platform-big-data-cloud.html.- Дата доступа: 24.09.2020.

10. IoT Platforms [Electronic resource].- Mode of access: http://www. tadviser. ru/index.php/ Article: IoT platforms.--Access date: 21.09 .2020$.

11. Visniakou U.A. Model and structure of multiagent system for collection and processing sound information / U.A. Vishniakou, B. H. Shaya // In science and technology collection of the seminar "Telecommunications: systems and networks, algebraic coding and security" - Minsk: BSUIR, 2019.- Pp. 18-21.

12. What we should build an IoT? [Электронный ресурс].- Режим доступа: https://habr.com/ru/post/472216/ - - Access date: 12.10 .2020 .

13. Getting Started with AWS IoT [Electronic resource].- Mode of access: https://docs.aws.amazon.com/ greengrass/latest/ developerguide/gg-gs.html.-- Access date: 12.10.2020.

14. AWS SDK JavaScript [Electronic resource].- Mode of access: https://aws.amazon. com/sdk-for-node-js/.-- Access date: 12.10.2020.

15. Running the NodeJS-app on Android [Electronic resource].- Mode of access: https://habr.com/ru/post/301442/.- - Access date: 12.10 .2020 .

16. IoT-Sensors [Electronic resource].- Mode of access: https://github.com/ AlexeySushkov/IoT-Sensors.- - Access date: 12.10.2020.

\section{ЛИТЕРАТУРА}

1. Мойзук, Б. Проектирование адаптивных пространственно-временных информационных систем для оценки рисков стихийных бедствий с помощью ASTIS / Б. Мойзук, Дж. Гензел, П. Давойне, Х. Мартин // Веб и беспроводные географические информационные системы, 2006. Рp. 146-157.

2. Парент, С. Semantic modeling for geographic information systems / С. Парент, С. Спассаприетра, Е. Зимяний Е // Энциклопедия систем баз данных, 2009.- С. 2571-2576.

3. Вишняков, В.А. Approach to distributed multi-agent system for processing sound information of the environment / В. А. Вишняков, В. Х. Сайя // Системный анализ и прикладная информатика, 2019, № 3.- С. 47-53.

4. Вишняков, В.А. Технологии интеллектуальной многоагентной обработки информации с блокчейн для систем управления / В.А. Вишняков, Б.Х. Сайя, А.Х. Аль-Масри, С.К. Аль-Хаджи // Сборник научных трудов ОСТИС-2019.- Минск: БГУИР, 2019.- С. 311-314.

5. Росляков, А. В. Интернет вещей: учеб. пособие / А.В. Росляков, С. В. Ваняшин, А. Ю. Гребешков.- Самара, ПГУТиИ, 2015.- 115 с.

6. Обзор лучших ІоТ платформ в 2019 году. Советы по выбору облачного решения [Электронный ресурс].- Режим доступа: https://www.edsson.com/ru/blog/article?id=iot-platforms.- Дата доступа:24.04.2020.

7. оТ платформа [Электронный ресурс].- Режим доступа: https://iot.ru/wiki/iot-platforma.- Дата доступа: 20.09.2020.

8. Things to know about the IoT Platform ecosystem [Электронный pecypc].- Режим доступа: https://iot-analytics. com/5-things-know-about-iot-platform/.- Дата доступа: 22.09.2020.

9. Big Data - облака интернета вещей: что такое IоТ-платформы и зачем они [Электронный ресурс].- Режим доступа: https://www.bigdataschool.ru/blog/iot-platform-big-data-cloud.html.- Дата доступа: 24.09.2020.

10. ІоТ платформы [Электронный ресурс]. - Режим доступа: http://www.tadviser. ru/index.php/Статья: ІоТ-платформы.Дата доступа: 21.09.2020.

11. Visniakou U.A. Модель и структура многоагентной системы сбора и обработки звуковой информации / U.A. Vishniakou, B. H. Shaya // B науч-техн. сборнике семинара «Телекоммуникации: системы и сети, алгебраическое кодирование и безопасность»- Минск: БГУИР, 2019. С. 18-21.

12. Что нам стоит ІоТ построить? [Электронный ресурс].- Режим доступа: https://habr.com/ru/post/472216/ - Дата доступа: 12.10 .2020$.

13. Начало работы с AWS IoT [Электронный ресурс].- Режим доступа: https://docs.aws.amazon.com/ greengrass/latest/ developerguide/gg-gs.html.- Дата доступа: 12.10.2020.

14. AWS SDK Джава скрипт [Электронный ресурс].- Режим доступа: https://aws.amazon.com/sdk-for-node-js/.- Дата доступа: 12.10 .2020$.

15. Запуск NodeJS-приложения на Android [Электронный ресурс].- Режим доступа: https://habr.com/ru/post/301442/.Дата доступа: 12.10 .2020 .

16. ІоТ-датчики [Электронный ресурс].- Режим доступа: https:/github.com/ AlexeySushkov/IoT-Sensors.- Дата доступа: 12.10 .2020 


$\begin{array}{ccc}\text { Поступила } & \text { После доработки } & \text { Принята к печати } \\ 13.11 .2020 & 01.05 .2021 & 01.06 .2021\end{array}$

ВИШНЯКОВ В.А., САЙЯ Б.Х.

\title{
МОАЕАИРОВАНИЕ СЕТИ ИНТЕРНЕТА ВЕЩЕЙ АМЯ МОНИТОРИНГА ЗВУКОВОЙ ИНФОРМАЦИИ НА ПМАТФОРМЕ КОМПАНИИ АМАЗОН
}

\begin{abstract}
Предметом исследований является моделирование структуры сети Интернета вещей (ИВ) для контроля звуковой информации на базе платформы ІоТ. Цель статьи - детализировать прочесс моделирования сети мониторинга звуковой информации на основе платформы ІоТ. Авторы предложили структуру мультиагентную систему (MAC) для мониторинга звуковой информации (МАСЗИ). Структура МАСЗИ включает в себя множество агентов звукового преобразования, анализа полученной от них информачии и принятия решений. Для моделирования МАСЗИ решено использовать сеть ИВ, которая включает датчики звука, платформу IоТ, сервис уведомлений и приложение пользователя. Предложена структура этой сети с использованием платформы компании Амазон. Приведен алгоритм моделирования сети интернета вещей для анализа звуковой информации на базе платформы AWS, включающий симулирование звуковых датчиков, передача этой информачии на платформу, аутентификачию датчиков, обработку информации по определенным правилам, формирование уведомления пользователю, Приведена детальная структура платформы AWS с описанием функций ее компонент таких как: шлюз устройств, машина правил, блок сертификатов, блок копий устройств, база данных, блок аналитики, сервис уведомлений. Приведен алгоритм подключения устройств к платформе AWS: создание сертификата устройства на платформе, формирование политики безопасности, правил обработки поступающей от устройств информации, тестирование сети. Показаны особенности алгоритма моделирования показаний датчиков звуковой информации на смартфоне, приведены шаги для организации его связи с платформой, выполнения процедур безопасности, посылки данных в виде MQTT сообщения и отображения снимаемой звуковой информации.
\end{abstract}

Ключевые слова: платформа, структура сети, эмулирование датчиков звука, коммуникачии, настройки.

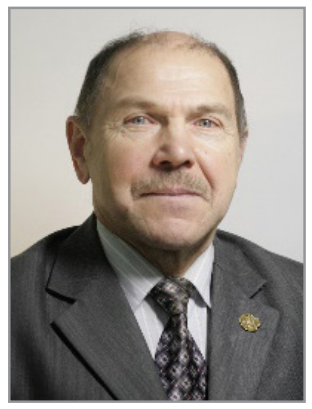

Vishniakou Uladzimir - doctor of technical science, professor of ICT department of Belarusian State University of Informatics and Radioelectronics. Research interest: information management and security, electronic business, intellectual management systems. Mingled of two doctoral counsels of thesis's defense. Author more 400 scientific publications including 6 monographs $(1-$ English), 4 study books with stamp of education Ministry, 8 volumes manual «Information management», 137 scientific articles.

Вишняков Владимир Анатольевич - д.т.н., профессор профессор БГУИР, каф. ИКТ. Область научных интересов: информационное управление и безопасность, электронный бизнес, интеллектуальные системы управления.

Член 2-х докторских Советов по защите диссертаций. Автор более 400 научных работ, в том числе 6 монографий (1 на английском языке), 4-х учебных пособий с грифом Министерства образования, 8-и томного учебного комплекса «Информационный менеджмент», 137 научных статей.

E-mail: vish2002@list.ru

Shaya Bahaa - master of technical science, PhD-student of ICT department of Belarusian State University of Informatics and Radioelectronics.

Сайя Бахаа - магистр технических наук, аспирант кафедры ИКТ БГУИР. 